\begin{tabular}{|c|c|c|}
\hline & $\begin{array}{c}\text { Науковий вісник НЛТУ України } \\
\text { Scientific Bulletin of UNFU } \\
\text { https://nv.nltu.edu.ua }\end{array}$ & \begin{tabular}{|c|c|c|} 
(c) & ISSN 1994-7836 (print) \\
BY ISSN 2519-2477 (online)
\end{tabular} \\
\hline & https://doi.org/10.36930/40310121 & $@ \bigotimes$ Correspondence author \\
\hline & $\begin{array}{l}\text { Article received } 28.12 .2020 \mathrm{p} \text {. } \\
\text { Article accepted } 04.02 .2021 \mathrm{p} \text {. }\end{array}$ & $\begin{array}{r}\text { N. B. Jaworski } \\
\text { nazarii.b.yavorskyi@lpnu.ua }\end{array}$ \\
\hline & UDC 004.942:519.632.6 & \\
\hline
\end{tabular}

Н. Б. Яворський, Н. А. Андрущак

Національний університет "Львівська політехніка", Львів, Украӥна

\title{
КОМБІНОВАНИЙ ЧИСЛОВО-АНАЛІТИЧНИЙ МЕТОД ПАРАМЕТРИЧНОГО ПРОЄКТУВАННЯ ТЕРАГЕРЦОВОГО ПІДКЛАДКОВОГО ПОЛЯРИЗАТОРА НА ПІДСТАВІ ДРОТЯНИХ СІТОК
}

\begin{abstract}
Розглянуто комбінований числово-аналітичний метод параметричного проєктування підкладкового поляризатора терагерцового електромагнітного випромінювання, побудованого на підставі дротяних сіток. Здійснено літературний огляд порівняльних характеристик можливих конструкцій поляризаторів різних типів та описано перевагу конструкцій на підставі дротяних сіток. Наведено огляд матеріалів, що використовують для виготовлення відповідних поляризаторів для різної довжини хвилі випромінювання. Проаналізовано методи, що застосовують для розрахунку характеристик і параметрів поляризаторів на підставі дротяних сіток. Розроблений числово-аналітичний метод параметричного проєктування базується на аналітичному розрахунку ефективних антивідбивних характеристик конструкції елементарної комірки поляризатора. У межах методу розроблено скінченно-елементну модель поляризатора, реалізовану за допомогою програмного забезпечення СОМSOL Multiphysics, що дає змогу уточнити характеристики конструкції елементарної комірки і можливості для їх розширення за допомогою числового моделювання методом скінченних елементів задачі поширення електромагнітних хвиль у цій конструкції в частотній області зі специфічними граничними умовами, що сукупно дає наукову новизну. Отримані результати моделювання добре узгоджуються з відомими експериментальними результатами та тісно корелюють з результатами моделювання, що отримали інші наукові групи, що свідчить про адекватність та практичну цінність методу для завдань проєктування поляризаторів терагерцового випромінювання з антивідбивними, високопропускними, низьковтратними та надійними характеристиками. Окрім цього, завдяки використанню числової скінченно-елементної складової, запропонований метод досить просто розширити способом зміни геометрії елементарної комірки для дослідження таких перспективних об'єктів, як багатошарові поляризатори чи поляризатори на підставі складніших мета- чи композиційних матеріалів.

Ключові слова: метод скінченних елементів; елементарна комірка; хвилевід; антивідбивна плівка; коефіцієнт пропускання.
\end{abstract}

\section{Вступ}

Пристрої для керування поширенням електромагнітними хвилями, що призначені для роботи в терагерцовому діапазоні (0,1-10 ТГц) [50], викликають значний інтерес дослідників. Це призводить до зростання кількості відповідних публікацій упродовж останнього часу, частину з яких наведено в посиланнях $[10,11,13$, 32, 34, 39, 41, 44, 50] і детальніше проаналізовано нижче. Причина такого інтересу заснована на сприятливих особливостях електромагнітних хвиль ТГц діапазону, таких як здатність проникати в непровідні матеріали, чутливість до складів матеріалів, низька енергія фотонів тощо [50]. Особливості проєктування та виробництва поляризаторів, які можуть працювати в діапазоні ТГц частот, полягають у вирішенні таких проблем, як багаторазове відбиття в товстих підкладках та труднощі досягнення великих значень пропускання, низьких втрат та надійних характеристик [1]. Незважаючи на те, що класичні аналітичні розв'язки таких задач показу- ють хорошу кореляцію результатів з натурними експериментами $[6,8,9,10,14,17,21,26,42,43]$, на практиці для усунення зазначених вище проблем, перед тим, як розпочати процес виготовлення поляризатора, потрібно виконати числові експерименти. Тому розроблення методу параметричного проєктування поляризаторів терагерцового електромагнітного випромінювання, що забезпечує розв'язок описаних проблем, $є$ актуальною задачею.

Об'єкт дослідження - параметричне проєктування поляризаторів терагерцового електромагнітного випромінювання.

Предмет дослідження - моделі та методи параметричного проєктування терагерцового підкладкового поляризатора на підставі дротяних сіток, що дають змогу забезпечити його антивідбивні, високопропускні, низьковтратні та надійні характеристики

Мета роботи - розробити комбінований числовоаналітичний метод, що дає змогу синтезувати параметри конструкції терагерцового підкладкового поляриза-

\section{Інформація про авторів:}

Яворський Назарій Борисович, канд. техн. наук, асистент, кафедра систем автоматизованого проєктування. Email: nazarii.b.yavorskyi@lpnu.ua; https://orcid.org/0000-0003-1312-7302

Андрущак Назарій Анатолійович, канд. техн. наук, доцент, кафедра систем автоматизованого проєктування. Email: nazariy.a.andrushchak@lpnu.ua; https://orcid.org/0000-0002-8248-404X

Цитування за ДСтУ: Яворський Н. Б., Андрущак Н. А. Комбінований числово-аналітичний метод параметричного проєктування терагерцового підкладкового поляризатора на підставі дротяних сіток. Науковий вісник НлТУ України. 2021, т. 31, № 1. С. $122-130$.

Citation APA: Jaworski, N. B., \& Andrushchak, N. A. (2021). Combined numerical-analytical method of terahertz substrate-based wire grid polarizer parametric design. Scientific Bulletin of UNFU, 31(1), 122-130. https://doi.org/10.36930/40310121 
тора на підставі дротяних сіток, які забезпечують його антивідбивні високопропускні, низьковтратні та надійні характеристики на підставі аналітичного розрахунку параметрів антивідбивної конструкції поляризатора та їх подальшого уточнення на підставі числового моделювання.

Для досягнення зазначеної мети визначено такі основні завдання:

1) проаналізувати можливі конструкції терагерцових поляризаторів;

2) дослідити методи проєктування поляризаторів на підставі дротяних сіток;

3) розробити комбінований числово-аналітичний метод проєктування, що забезпечує антивідбивні високопропускні, низьковтратні та надійні характеристики;

4) верифікувати розроблений метод шляхом порівняння результатів 3 відомими, отриманими іншими науковими групами.

Наукова новизна отриманих результатів дослідження - на підставі об'єднання аналітичних розрахунків антивідбивної конструкції поляризатора та числового моделювання задачі поширення електромагнітного випромінювання в цій конструкції набули подальшого розвитку моделі та методи параметричного проєктування терагерцового підкладкового поляризатора на підставі дротяних сіток, що дає змогу забезпечити його антивідбивні, високопропускні, низьковтратні та надійні характеристики.

Практична значущість результатів дослідження результати застосування розробленого методу узгоджуються в межах 1 \% похибки 3 передбачуваними теоретичними розрахунками, що свідчить про їх адекватність та точність. Наведений метод може бути використаний для розв'язку задач параметричного проєктування терагерцових поляризаторів 3 антивідбивними, високопропускними, низьковтратними та надійними характеристиками, що становить практичну цінність.

Аналіз останніх досліджень та публікацій. Для керування поляризацією використовують феномени, що виникають в анізотропних середовищах, де швидкість поширення чи розсіювання хвилі в різних напрямках $\epsilon$ різною, або феномени асиметричного поширення хвиль при їх відбитті та заломленні [36, 40, 41]. Основні конструкції лінійних поляризаторів можна поділити на бірефракційні, відбивні та дихроїчні [36, 37, 40, 41, 49]. Більшість наявних на цей час поляризаторів терагерцового випромінювання виготовляють як підвид дихроїчних - поляризатори на підставі дротяних сіток [10, 11, 13, 31, 32, 34, 39, 42, 50]. Вони є дешеві та прості у виробництві. Вибираючи необхідні товщину та період сітки, можна створити поляризатор для необхідного діапазону частот.

Принципи розрахунку параметрів конструкцій поляризаторів на підставі дротяних сіток наведено в [27, 28, $31,41,46]$. Проєктування такого поляризатора зі заданими характеристиками можна виконувати методом гомогенізації на підставі теорії ефективного середовища (effective medium theory, EMT [27]), що виражається принципом ефективної однорідності (еквівалентної гомогенності), при якому вхідна модель неоднорідного середовища замінюється на аналогічну модель однорідного середовища 3 ефективними, тобто дещо усередненими характеристиками $[6,19,35]$. У такому контексті цю теорію застосовують для знаходження ефективного показника заломлення окремо для ТЕ та ТМ поляризацій вхідного електромагнітного випромінювання на підставі добре відомої моделі Друде [6, 19, 27, 28, 46].

Незважаючи на те, що класичні аналітичні розв'язки на підставі рівнянь Френеля та теорії ефективного середовища $[6,8,9,10,14,17,21,26,42,43]$ показують добру кореляцію результатів з натурними експериментами, на практиці для усунення згаданих вище проблем багаторазового відбиття на товстих підкладках та труднощів досягнення великих значень пропускання, низьких втрат та надійних характеристик, перед тим, як розпочати процес виготовлення поляризатора терагерцового випромінювання, повинні бути проведені числові експерименти. Окрім цього, такі числові розрахунки можна легко розширити на складніші перспективні конструкції багатошарових поліризаторів [11, 42, 50], чи поляризаторів на підставі мета- або композитних матеріалів $[5,18,25]$. Найчастіше для синтезу характеристик поляризаторів використовують числові моделі, що базуються на суворому аналізі сполучених хвиль (Rigorous coupled-wave analysis, RCWA) [9, 27, 32, 46, 48], методі скінченних різниць часової області (Finite-difference time-domain method, FDTD) $[11,16,28]$ та методі скінченних елементів (Finite element method, FEM) [13, 42, 44, 47].

Методи та матеріали дослідження: метод гомогенізації $[6,8,9,10,14,17,21,26,42,43]$, метод розрахунку діелектричних плівок $[8,9,17]$, метод скінченних елементів для розв'язку задач поширення електромагнітних хвиль [13, 42, 44, 47], контрольні результати обчислень сторонніх наукових груп для верифікації [43].

\section{Результати дослідження та їх обговорення}

Розглянемо лінійні поляризатори, що найчастіше використовують в інженерії. Їх можна поділити на бірефракційні (двопроменезаламні), відбивні та дихроїчні [36, 37, 40, 41]:

- Бірефракційні поляризатори, зазвичай, виготовляють у вигляді двох кристалічних призм, матеріал яких $\epsilon$ анізотропним щодо швидкості поширення хвиль у різних напрямках середовища. Такі поляризатори, порівняно з іншими, мають найбільший коефіцієнт пропускання. До недоліків можна віднести їх громіздкість та відносно малий робочий кут падіння променя, обмежений кількома десятками градусів [36, 41].

- Відбивні поляризатори будують як одна чи кілька пластин з плоскою відполірованою поверхнею, на яку хвиля потрапляє під кутом Брюстера. Інтенсивності відбитих та пропущених хвиль визначаються за допомогою формул Френеля $[8,36]$. Вони різні для різних поляризацій, а тому відбиті хвилі завжди частково поляризовані. Для кута Брюстера відбита хвиля буде поляризована на 97-99,5\% в межах 5$10^{\circ}$. Такі поляризатори мають досить обмежений робочий діапазон частот та дуже чутливі до перекосів і розфокусування променів [36, 41].

- Дихроїчні поляризатори базуються на властивості анізотропних середовищ по-різному поглинати хвилі залежно від напрямку поширення. Такі поляризатори виготовляють у вигляді плоскопаралельних пластин. Компонента коливань хвилі, яка збігається $з$ напрямом пластини, пропускається 3 мінімальним розсіюванням, а ортогональна до неї компонента майже повністю поглинається $[36,40]$. Дихроїчні поляризатори дешеві та прості у виробництві. До недоліків можна віднести високу чутливість до температури довколишнього середовища та значно менший коефіцієнт пропускання порівняно з бірефракційними [41].

- Одним з підвидів дихроїчних поляризаторів $є$ відомі досить давно $[7,27]$ поляризатори на підставі дротяних сіток або граток (Wire Grid Polarizers, WGP, рис. 1). Хвилі, що поля- 
ризовані ортогонально до розміщення канавок сітки, майже повністю ними розсіюються. Вибираючи необхідні товщину та період сітки, можна створити поляризатор для заданого діапазону частот. Коефіцієнт пропускання у практичних реалізаціях досягає 50-80\%. Значною перевагою є також дуже великий робочий кут падіння [41]. Більшість наявних терагерцових поляризаторів виготовляють як WGP $[13,16$, $26,31,33,42,45,50]$.

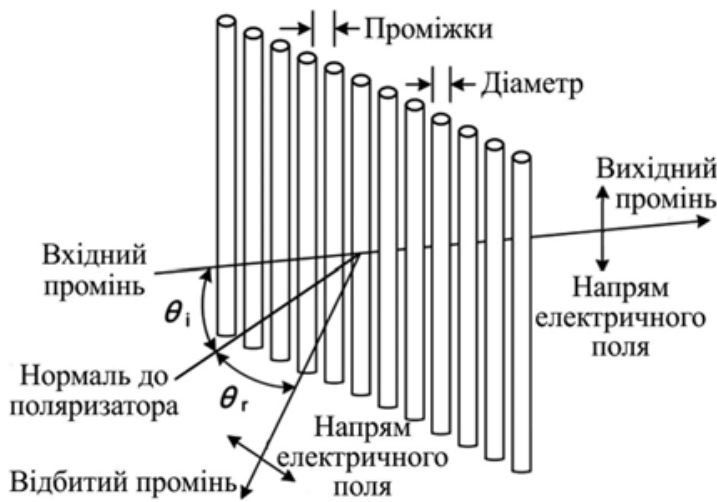

Рис. 1. Схематичне зображення поляризатора на підставі дротяних сіток [31]

WGP можна поділити на поляризатори з підкладкою (Substrate-based WGP, SWGP) та окремо стоячі, безпідкладкові WGP (Freestanding WGP, FWGP) чи просто FWP [31]. Підкладка поляризатора, залежно від використовуваних матеріалів, не є обов'язковою, однак поляризатори на підкладці простіші у виготовленні, стійкіші до механічних навантажень та менш чутливі до зміни температури довколишнього середовища [44]. 3 іншого боку, наявність підкладки збільшує втрати коефіцієнта пропускання [44]. Нові підходи пропонують варіанти з багатошаровими WGP $[11,42,50]$, наприклад двошарові (Bilayer WGP) [11]. Детальний огляд конструкцій таких поляризаторів можна знайти в [50]. У таблищі наведено деякі матеріали, з яких практично виготовляють WGP (докладніше в [50]).

Таблиця. Характеристики матеріалів для виготовлення поляризаторів

\begin{tabular}{|c|c|c|c|}
\hline $\begin{array}{c}\text { Довжина хвилі } \lambda \\
{[\mu \mathrm{M}]}\end{array}$ & Матеріал сітки & $\begin{array}{c}\text { Матеріал } \\
\text { підкладки }\end{array}$ & Посилання \\
\hline $0,170-0,285$ & $\mathrm{TiO}_{2}$ & \multirow{6}{*}{ - } & \multirow{6}{*}{ [41] } \\
\hline $0,185-0,195$ & $\mathrm{Cr}_{2} \mathrm{O}_{3}$ & & \\
\hline $0,225-0,375$ & W & & \\
\hline $0,275-0,500$ & $\mathrm{Ir}$ & & \\
\hline $0,325-0,500$ & $\mathrm{Al}$ & & \\
\hline $0,340-0,425$ & $\mathrm{Si}$ & & \\
\hline $0,380-0,780$ & $\mathrm{Al}$ & $\mathrm{SiO}, \mathrm{SiN}$ & {$[28]$} \\
\hline 0,450 & $\mathrm{Al}$ & $\mathrm{SiO}_{2}$ & {$[2]$} \\
\hline $0,400-0,700$ & $\mathrm{Si}, \mathrm{Ag}, \mathrm{Au}, \mathrm{Al}$ & $\mathrm{Si}$ & [47] \\
\hline $0,550-0,650$ & $\mathrm{Si}$ & - & [15] \\
\hline $0,650-1,55$ & $\mathrm{Al}, \mathrm{Al}_{2} \mathrm{O}_{3}$ & $\mathrm{SiO}_{2}$ & {$[24]$} \\
\hline 1,500 & $\mathrm{Si}$ & - & [9] \\
\hline 1,550 & $\mathrm{SiO}_{2}$ & - & [46] \\
\hline 1,550 & $\mathrm{Ag}$ & - & [27] \\
\hline 1,550 & $\mathrm{Au}$ & - & [12] \\
\hline $15-1500$ & $\left(\mathrm{C}_{2} \mathrm{H}_{4}\right)_{\mathrm{n}},\left(\mathrm{C}_{3} \mathrm{H}_{6}\right)_{\mathrm{n}}$ & $\mathrm{SiO}_{2}$ & [45] \\
\hline $100-300$ & $\mathrm{Al}$ & - & {$[44]$} \\
\hline $100-3000$ & W & $\begin{array}{c}\text { Полімерна } \\
\text { мембрана }\end{array}$ & {$[33,34]$} \\
\hline $135-1500$ & CNT & $\mathrm{Al}_{2} \mathrm{O}_{3}$ & [39] \\
\hline $150-1500$ & $\mathrm{Al}$ & $\mathrm{Si}, \mathrm{SiO}_{2}$ & {$[16]$} \\
\hline $180-300$ & $\mathrm{Cu}, \mathrm{Ti}, \mathrm{Sn}, \mathrm{Ni}, \mathrm{In}$ & $\mathrm{Si}$ & {$[10]$} \\
\hline $600-880$ & $\mathrm{~W}$ & - & [31] \\
\hline
\end{tabular}

Методи проєктування поляризаторів на підставі дротяних сіток. Розглянемо принципи розрахунку параметрів конструкцій WGP [27, 28, 31, 41, 46]. Схематичне зображення такого поляризатора зображено на рис. 2 .

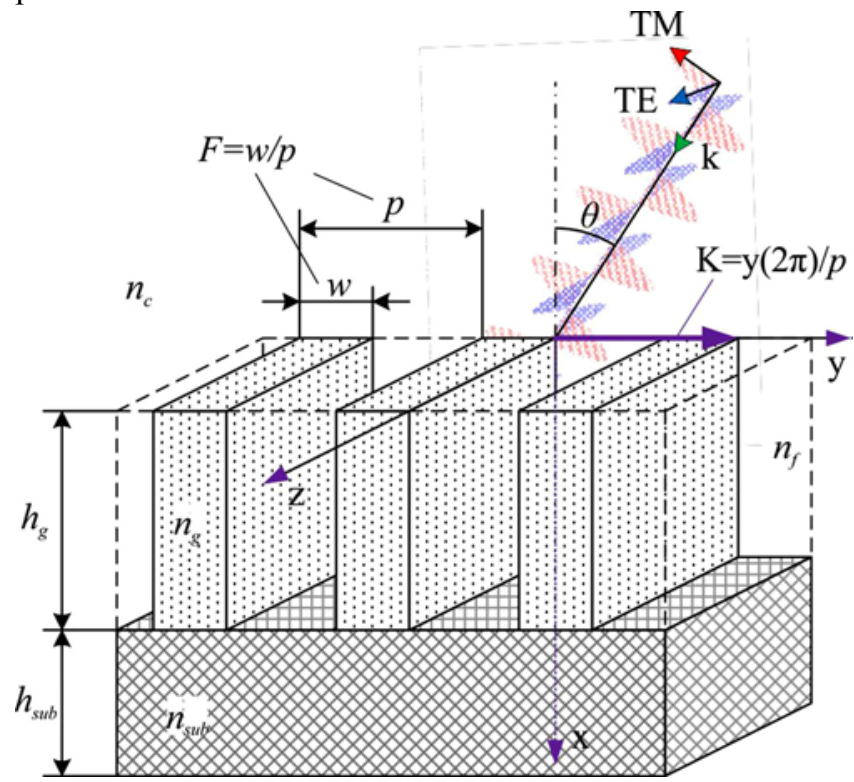

Рис. 2. Структурна модель поляризатора на підставі дротяних сіток

Для уникнення явища дифракції на періодичній структурі сітки іiі період повинен задовольняти умову нульового порядку $[41,46]$ :

$$
p<\frac{\lambda_{0}}{n+\sin \theta},
$$

де: $p$ - період сітки; $n$ - показник заломлення поляризатора; $\theta$ - кут падіння променя на поляризатор.

Тобто період сітки (1) повинен бути таким, щоб максимально відсікти всі можливі ненульові дифракційні порядки. Він має бути менший за довжину хвилі, на яку розрахований поляризатор. Конструкція поляризатора принципово допускає комбінацію більше ніж двох середовищ, характеристики яких позначаємо як: $n_{g}-$ показник заломлення сітки; $n_{c}-$ показник заломлення довколишнього середовища, 3 якого приходить хвиля; $n_{f}-$ показник заломлення пустот сітки, що не обов'язково повинні бути такими ж, як довколишнє середовище; $n_{s u b}$ - показник заломлення підкладки, на якій змонтована сітка. На рис. 2 глибину канавок сітки та висоту підкладки позначено як $h_{g}$ та $h_{s u b}$, відповідно; $\mathbf{K}=\mathbf{y}(2 \pi) / p$ - це вектор періодичності сітки; $w$ - ширина канавок; $F=w / p-$ коефіцієнт заповнення сітки.

Приймемо $n_{c}=n_{f}$. У найпростішому випадку, якщо $n_{g}=n_{s u b}$ та $n_{f}<n_{g}$, то дифракційні порядки \pm 1 та вищих порядків будуть відсікатися при [9]:

$$
\frac{\lambda}{p}=n_{f} \sin \theta \cos \phi+\sqrt{n_{g}^{2}-n_{f}^{2} \sin ^{2} \theta \cos ^{2} \phi},
$$

де $\phi$ - азимут площини падіння (кут між ТЕ та $\mathbf{K}$ ), що в загальному випадку не ортогональний. Якщо азимут рівний $90^{\circ}$, то отримаємо вираз (1).

Проєктування такого поляризатора зі заданими характеристиками можна проводити на підставі ЕМТ методом гомогенізації $[6,19,27,35]$. У такому контексті цю теорію застосовують для знаходження ефективного 
показника заломлення окремо для ТЕ та ТМ поляризацій на підставі моделі Друде [6, 19, 27, 28, 46]. 3 диференціальних рівнянь цієї моделі випливає, що у випадку ТЕ поляризації, тобто коли напруженість електричного поля є ортогональною до вектора періодичності сітки $(\mathbf{E} \perp \mathbf{K})$, це електричне поле $\epsilon$ дотичним до канавок сітки і тому майже не змінюється при проходженні крізь них [9]. Натомість, виходячи з добре відомих рівнянь Максвелла, електрична індукція $\mathbf{D}=\varepsilon_{0} \varepsilon \mathbf{E}$ буде змінюватися при проходженні хвилі зі середовища в середовище. Для діелектриків $\left(\varepsilon=n^{2}\right)$ це приводить до виразу:

$$
n_{\text {eff }, T E}^{2}=(1-F) \cdot n_{f}^{2}+F \cdot n_{g}^{2} .
$$

Останній вираз також відомий як формула Сільберштейна. Він $є$ наближенням першого порядку і в загальному випадку, за потреби, можна знайти точніші вирази вищих порядків [9].

Для ТМ поляризації напруженість магнітного поля $є$ ортогональною до вектора періодичності сітки $(\mathbf{H} \perp \mathbf{K})$. Тепер поле індукції $\mathbf{D} \in$ дотичним до канавок сітки і воно буде незмінним при проходженні хвилі зі середовища в середовище. Звідси отримаємо обернений до (3) вираз:

$$
n_{e f f, T M}^{2}=\frac{1}{(1-F) / n_{f}^{2}+F / n_{g}^{2}}=\frac{n_{f}^{2} n_{g}^{2}}{(1-F) n_{g}^{2}+F n_{f}^{2}} .
$$

Глибину канавок сітки вибирають так, щоб максимально уникнути ефекту відбиття хвиль. Для цього використовують теорію діелектричних плівок [8], розглядаючи поляризатор як ефективну антивідбивну плівку (antireflection film, AR). Річ у тому, що, базуючись на добре відомих формулах Френеля, які визначають інтенсивність заломленої та відбитої хвиль при її проходженні через плоску межу розділу двох середовищ із різними показниками заломлення $n_{1}$ та $n_{2}$ можна показати [8, 9, 27], що коефіцієнти відбиття та пропускання хвиль через діелектричну плівку мають періодичну залежність від іiі товщини. Фомули Френеля у загальному випадку записують як:

$$
\begin{aligned}
t_{T E} & =\frac{2 n_{1} \cos \theta_{i}}{n_{2} \cos \theta_{i}+n_{1} \cos \theta_{t}} A_{T E}, & r_{T E} & =\frac{n_{2} \cos \theta_{i}-n_{1} \cos \theta_{t}}{n_{2} \cos \theta_{i}+n_{1} \cos \theta_{t}} A_{T E}, \\
t_{T M} & =\frac{2 n_{1} \cos \theta_{i}}{n_{1} \cos \theta_{i}+n_{2} \cos \theta_{t}} A_{T M}, & r_{T M} & =\frac{n_{1} \cos \theta_{i}-n_{2} \cos \theta_{t}}{n_{1} \cos \theta_{i}+n_{2} \cos \theta_{t}} A_{T M},
\end{aligned}
$$

де: $t$ - амплітудний коефіцієнт пропускання; $r$ - амплітудний коефіцієнт відбиття; $\theta_{i}-$ кут падіння променя; $\theta_{t}$ - кут заломлення променя; $A$ - амплітуда коливань. Звідси (енергетичні) коефіцієнти пропускання $\mathcal{T}$ та відбиття $\mathcal{R}$ виражаються як (тут не враховано ослаблення):

$$
\mathcal{T}=\frac{n_{2} \cos \theta_{t}|t|^{2}}{n_{1} \cos \theta_{i}|A|^{2}}, \quad \mathcal{R}=\frac{|r|^{2}}{|A|^{2}}, \quad \mathcal{R}+\mathcal{T}=1 .
$$

Для діелектричної плівки коефіцієнти відбиття та пропускання можна переписати як [8]:

$$
\begin{aligned}
\mathcal{T} & =\frac{n_{3} \cos \theta_{3}}{n_{1} \cos \theta_{1}} \cdot \frac{t_{12}^{2} t_{23}^{2}}{1+r_{12}^{2} r_{23}^{2}+2 n_{2} r_{23} \cos 2 \beta} \cdot \frac{1}{|A|^{2}}, \\
\mathcal{R}=\frac{|r|^{2}}{|A|^{2}} & =\frac{r_{12}^{2}+r_{23}^{2}+2 r_{12} r_{23} \cos 2 \beta}{1+r_{12}^{2} r_{23}^{2}+2 r_{12} r_{23} \cos 2 \beta} \cdot \frac{1}{|A|^{2}}, \quad \beta=\frac{2 \pi}{\lambda_{0}} n_{2} h \cos \theta_{2},
\end{aligned}
$$

де індекси 1,2,3 визначають довколишнє середовище, плівку та підкладку, на якій вона лежить, відповідно (рис. 3).

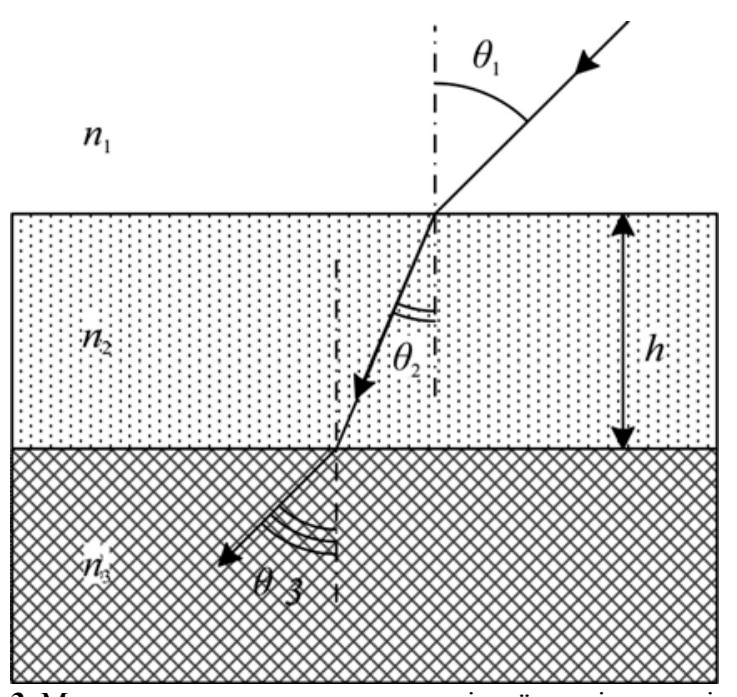

Рис. 3. Модель поширення електромагнітної хвилі через діелектричну плівку

Виходячи із (7) значення коефіцієнтів відбиття та пропускання не змінюються при заміні $\beta$ на $(\beta \pm \pi)$, тобто залежність $\epsilon$ періодичною. Отже, для ТМ поляризації висота плівки визначається виразом [8]:

$$
h=\frac{(2 m+1) \lambda_{0}}{4 n_{2} \cos \theta_{2}}, \quad m=0,1,2,3, \ldots,
$$

де $\theta_{2}$ - кут заломлення променя у плівці. При цьому коефіцієнт відбиття плівки буде мінімальним, якщо $n_{1}<n_{2}$ і максимальним в протилежному випадку. При ортогональному падінні променя на плівку коефіцієнт відбиття буде дорівнювати нулю $\left(\mathcal{R}_{T M}=0\right)$, якщо виконується така умова:

$$
n_{2}=\sqrt{n_{1} n_{3}}
$$

або іншими словами, використовуючи (4), (9) та прийнявши $n_{f}=n_{c}=n_{1}, n_{s u b}=n_{3}, n_{\text {eff }, T M}=n_{2}-$ якщо коефіцієнт заповнення буде дорівнювати:

$$
F=\frac{n_{c} n_{g}^{2} n_{s u b}-n_{c}^{2} n_{g}^{2}}{n_{c} n_{g}^{2} n_{s u b}-n_{c}^{3} n_{s u b}} .
$$

У такий самий спосіб, виходячи з (7), можна вивести періодичну залежність коефіцієнтів відбиття та пропускання від довжини хвилі. При цьому варто враховувати те, що показник заломлення у загальному випадку є функцією від довжини хвилі, тому залежність буде нелінійною.

Товщину підкладки вибирають за можливості мінімальною, щоб уникнути ослаблення випромінювання в iii шарі. Матеріал підкладки потрібно обирати так, щоб його показник заломлення та коефіцієнт ослаблення були мінімальними. Для розрахунку товщини підкладки застосовують такий самий підхід, як і до розрахунку глибини канавок сітки (8).

Значення коефіцієнта відбиття для ТЕ поляризації буде тим більшим, чим більший показник заломлення сітки $n_{g}$, тому матеріал сітки потрібно підбирати відповідно до цього твердження. Для цього можна використовувати навіть непрозорі для заданого діапазону частот матеріали, наприклад метали для видимого електромагнітного випромінювання, у яких показник заломлення має дуже великі значення, внаслідок чого коефіцієнт відбиття досягатиме $\mathcal{R}_{T E}=1$. 
Використання методу скінченних елементів. Автори розробили скінченно-елементну модель терагерцового підкладкового поляризатора на підставі дротяних сіток, реалізовану за допомогою програмного забезпечення COMSOL Multiphysics. Суть моделі полягає у скінченно-елементному наближенні задачі розповсюдження електромагнітних хвиль у частотній області всередині елементарної комірки поляризатора, яку розглядають як хвилевід із певними граничними умовами. Хвильове рівняння електричного поля у частотній області записують як:

$$
\nabla \times(\nabla \times \mathbf{E})=(n+\mathrm{i} \kappa)^{2}\left(\frac{2 \pi}{\lambda}\right)^{2} \mathbf{E} .
$$

де $\kappa$ - коефіцієнта ослаблення $\hat{n}^{2}=(n+\mathrm{i} \kappa)^{2}$.

Оскільки структура на рис. 2 не змінюється в напрямку осі $z$, iї можна спростити до 2D-моделі. Оскільки структура поляризатора періодична у напрямку осі у , тобто має дискретну симетрію трансляції [49, 23], iï можна спростити до елементарної комірки, показаної на рис. 4.

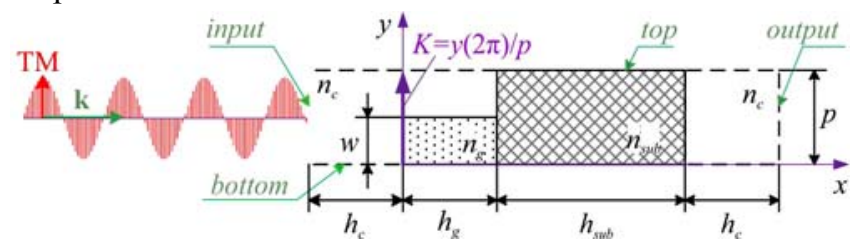

Рис. 4. Модель елементарної комірки поляризатора

Коли частина хвилі поширюється через об'єкт 3 вищим показником заломлення, ця частина затримується. Отже, хвиля стає збуреною об'єктом. Хвилі в періодичних структурах приймають таку ж симетрію і періодичність, що і сама структура. Функція огинаючої може описувати періодичність структури відповідно до теореми Блоха, також відомої як теорема Флоке [23, 49]. Теорема показує, що розв'язки таких задач як (11) на періодичних структурах можна подати у вигляді такої комбінації:

$$
\mathbf{E}(x, y)=\mathbf{E}_{\mathbf{k}}(x, y) e^{i \mathbf{k} \cdot \mathbf{r}},
$$

де $\mathbf{E}_{\mathbf{k}}(x, y) \in$ періодичною функцією огинаючої, яка описує структуру, тобто $\mathbf{E}_{\mathbf{k}}(x, y)=\mathbf{E}_{\mathbf{k}}\left(x+\mathbf{K}_{x}, y+\mathbf{K}_{y}\right)$ для всіх векторів періодичності $\mathbf{K}=\mathbf{y}(2 \pi) / p ; \mathbf{k}-$ хвильовий вектор Блоха, тобто хвильовий вектор вхідної хвилі. Тож періодичну граничну умову Флоке можна застосувати до верхньої та нижньої сторін елементарної комірки на рис. 2:

$$
\mathbf{E}_{\text {top }}=\mathbf{E}_{\text {bottom }} e^{\mathrm{ik} \cdot\left(\mathbf{r}_{\text {top }}-\mathbf{r}_{\text {bottom }}\right)} \text {. }
$$

Будь-яку структуру, яка пропускає електромагнітні хвилі вздовж себе, можна розглядати як хвилевід. Оскільки хвилевід, що розглядається, вважається нескінченно довгим, область, яка нас цікавить, поширюється до нескінченності вздовж напрямку х . Необхідно урізати цю область до скінченної, розмістивши фіктивні площини на кожній з двох сторін поляризатора і визначити так звані граничні умови портів хвилеводу, що є граничними умовами третього роду:

$$
\begin{array}{lll}
\mathbf{n} \times(\nabla \times \mathbf{E})+P(\mathbf{E})=\mathbf{U}^{i n c} & \text { on } & \text { top, } \\
\mathbf{n} \times(\nabla \times \mathbf{E})+P(\mathbf{E})=0 & \text { on } & \text { bottom, }
\end{array}
$$

де: $\mathbf{n}$ - нормаль до границі; $P(\mathbf{E})$ - оператор, який описує режими розсіяної хвилі; та $\mathbf{U}^{i n c}-$ оператор, який описує специфічну для аналізу вхідну хвилю $\mathbf{E}^{\text {inc }}$ (деталі в $[22,29,30])$. Відповідно до таких граничних умов модельна висота вільного простору $h_{c}$ може бути обрана довільно.

Також для повноти повинні бути застосовані умови безперервності поля до інтерфейсів між вільним простором, сіткою та підкладкою:

$$
\mathbf{n} \times\left(\mathbf{E}_{i}-\mathbf{E}_{j}\right)=0, \mathbf{n} \cdot\left(\varepsilon_{0} \varepsilon_{r i} \mathbf{E}_{i}-\varepsilon_{0} \varepsilon_{r j} \mathbf{E}_{j}\right)=0 .
$$

Елементарна комірка на рис. 4 може бути дискретизована сіткою скінченних елементів, на кожному з яких можна знайти наближення електричного поля [20]. Внаслідок цього отримаємо систему лінійних рівнянь типу:

$$
[K]\{\mathbf{E}\}=\{f\},
$$

де невідомими $є$ вузлові значення електричного поля (11) за граничних умов (13)-(15). Розв'язок можна зручно знайти за допомогою будь-якого відомого прямого або ітераційного методу.

На вхідній стороні отримане апроксимоване електричне поле можна розкласти на вхідну хвилю $\mathbf{E}^{\text {inc }} \mathrm{i}$ відбиту хвилю $\mathbf{E}^{\text {ref }}$, що своєю чергою виражається через коефіцієнт відбиття $\mathcal{R}$ :

$$
\mathbf{E}=\mathbf{E}^{i n c}+\mathbf{E}^{r e f}=\mathbf{E}^{i n c} e^{\mathrm{i} \frac{2 \pi}{\lambda} x}+\sqrt{\mathcal{R}} \mathbf{E}^{i n c} e^{-\mathrm{i} \frac{2 \pi}{\lambda} x} .
$$

На протилежній вихідній стороні це електричне поле можна розкласти аналогічно на передану хвилю $\mathbf{E}^{\text {trans }}$, або через пропускання $\mathcal{T}$ :

$$
\mathbf{E}=\mathbf{E}^{\text {trans }}=\sqrt{\mathcal{T}} \mathbf{E}^{i n c} e^{\mathrm{i} \frac{2 \pi}{\lambda} x},
$$

де $\mathcal{R}$ та $\mathcal{T}$ можна виразити як:

$$
\begin{gathered}
R=\frac{1}{p}\left(\int_{S} \frac{E\left(x_{\text {input }}, y\right)-E^{i n c} e^{i \frac{2 \pi}{\lambda} x_{\text {input }}}}{E^{i n c} e^{i \frac{2 \pi}{\lambda} x_{\text {input }}}} d y\right)^{2}, \\
\mathcal{T}=\frac{1}{p}\left(\int_{S} \frac{\mathbf{E}\left(x_{\text {output }}, y\right)}{\mathbf{E}^{\text {inc }} e^{\mathrm{i} \frac{2 \pi}{\lambda} x_{\text {output }}}} d y\right)^{2}, \mathcal{R}+\mathcal{T}+\mathcal{A}=1,
\end{gathered}
$$

де $\mathcal{A}$ - коефіцієнт поглинання, який з'являється завдяки коефіцієнту ослаблення матеріалу $\kappa$. Поляризатори також часто характеризуються коефіцієнтом екстинкції, що вимірюється в децибелах:

$$
E R=10 \log _{10} \frac{\mathcal{T}_{\text {trans }}}{\mathcal{T}_{\text {block }}},
$$

де $\mathcal{T}_{\text {trans }}$ та $\mathcal{T}_{\text {block }}$ - пропускання для орієнтації поляризатора з максимальним і мінімальним пропусканням відповідно, наприклад, для ТМ і ТЕ.

Верифікація результатів обчислення. Розроблена модель була протестована на відомих результатах обчислень, отриманих іншими науковими групами, зокрема [43], де автори аналітично розрахували коефіцієнт пропускання для різних матеріалів сітки, наприклад, для срібної сітки $(\mathrm{Ag})$ висотою $h_{g}=0,13$ мкм, періодом $p=0,14$ мкм, коефіцієнтом заповнення $F=0,4$ та підкладки 3 триацетилцелюлози (ТАC) 3 висотою $h_{s u b}=10$ мкм. Для цього випадку характеристики були $n_{s u b}=1,52$ та $\kappa_{s u b}=0,05$. Відповідне порівняння результатів показано на рис. 5. Похибка становить менше $1 \%$. 


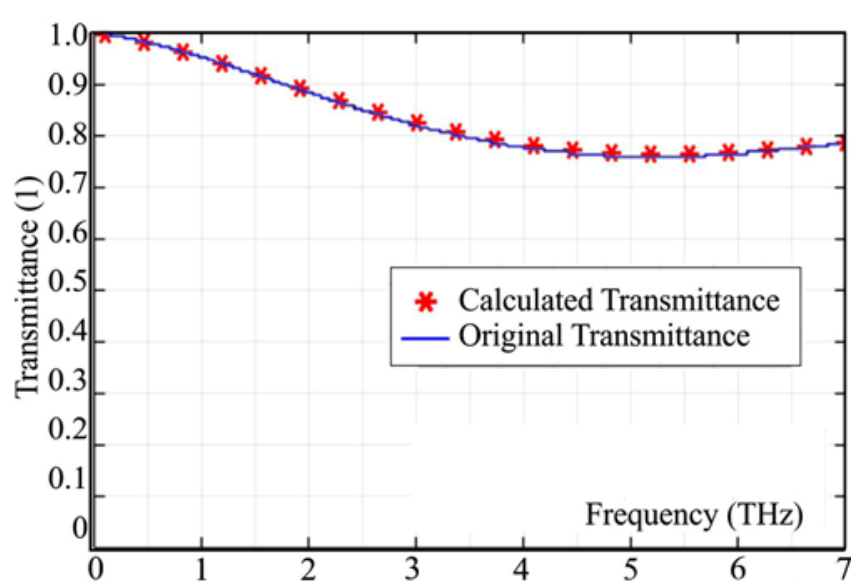

Рис. 5. Розрахований коефіцієнт пропускання $\mathrm{Ag}$ для ТАC порівняно з результатами [43]

Застосування розробленого числово-аналітичного методу параметричного проєктування WGP. Hехай необхідно спроєктувати WGP для робочої частоти електромагнітного випромінювання 0,300 ТГц, що відповідає довжині хвилі $\lambda_{0}=999,308$ мкм. Спираючись на дані з таблиці візьмемо за основу алюміній (Al) та кварцову підкладку $\left(\mathrm{SiO}_{2}\right)$. При заданій довжині хвилі показники заломлення становлять $n_{g, \mathrm{Al}}=965,69$ та $n_{s u b, \mathrm{SiO}_{2}}=2,4692$, а коефіцієнти ослаблення $\kappa_{g, \mathrm{Al}}=1006,7$ та $\kappa_{s u b, \mathrm{SiO}_{2}}=0,0017028$ (рис. 6) $[1,38]$.

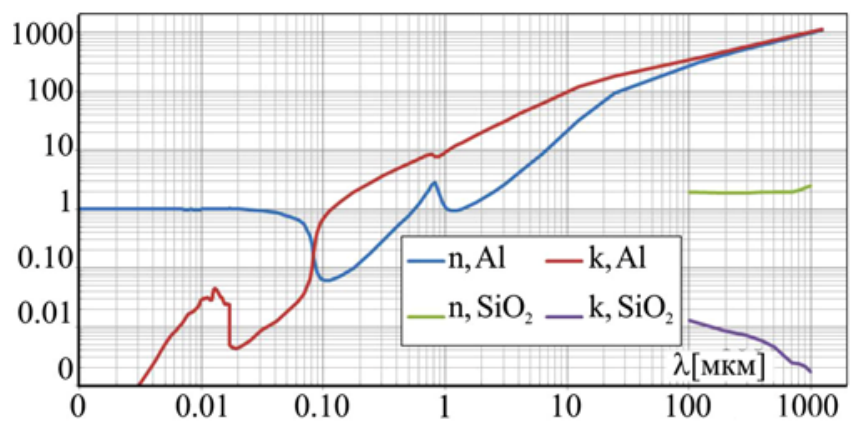

Рис. 6. Показник заломлення і коефіцієнт ослаблення алюмінію (Al) та кварцу $\left(\mathrm{SiO}_{2}\right)$ для різної довжини хвилі електромагнітного випромінювання $[1,38]$

Виберемо період сітки так, щоб задовольнити (1) та (2), $p=100$ мкм. Згідно 3 (10), оптимальним коефіцієнтом заповнення буде $F=0,595$. Згідно з (8), щоб виконувалася умова $\mathcal{R}_{T M}=0$ (та $\mathcal{T}_{T M}=1$, відповідно), при ортогональному падінні променя, оптимальна глибина канавок сітки має бути $h_{g}=(2 \cdot 0+1) \lambda_{0} / 4=249,827$ мкм. Тут $m=0$ та $n=n_{c}$. У реальних умовах коефіцієнт пропускання буде менший, внаслідок ослаблення хвилі. Оскільки показник заломлення та коефіцієнт ослаблення алюмінію є дуже великий для заданої довжини хвилі, отримуємо $\mathcal{R}_{T E}=1$ та $\mathcal{T}_{T E}=0$. Товщину підкладки шукаємо аналогічно до глибини канавок сітки за допомогою (8), звідки отримаємо $h_{\text {sub }}=(2 \cdot 5+1) \lambda_{0} /\left(4 n_{\text {sub }}\right)=1112,6$ мкм. Тут $m=5$.

Модель WGP з отриманими параметрами була досліджена в системі моделювання фізичних процесів на підставі методу скінченних елементів COMSOL Multiphysics 5.4.

Обговорення результатів дослідження. Як видно 3 рис. 7 , попередньо знайдена глибина канавок поляризатора та висота його підкладки є оптимальними і задо- вольняють вираз (8). 3 рис. 8 видно, що знайдений коефіцієнт заповнення сітки також є оптимальним.
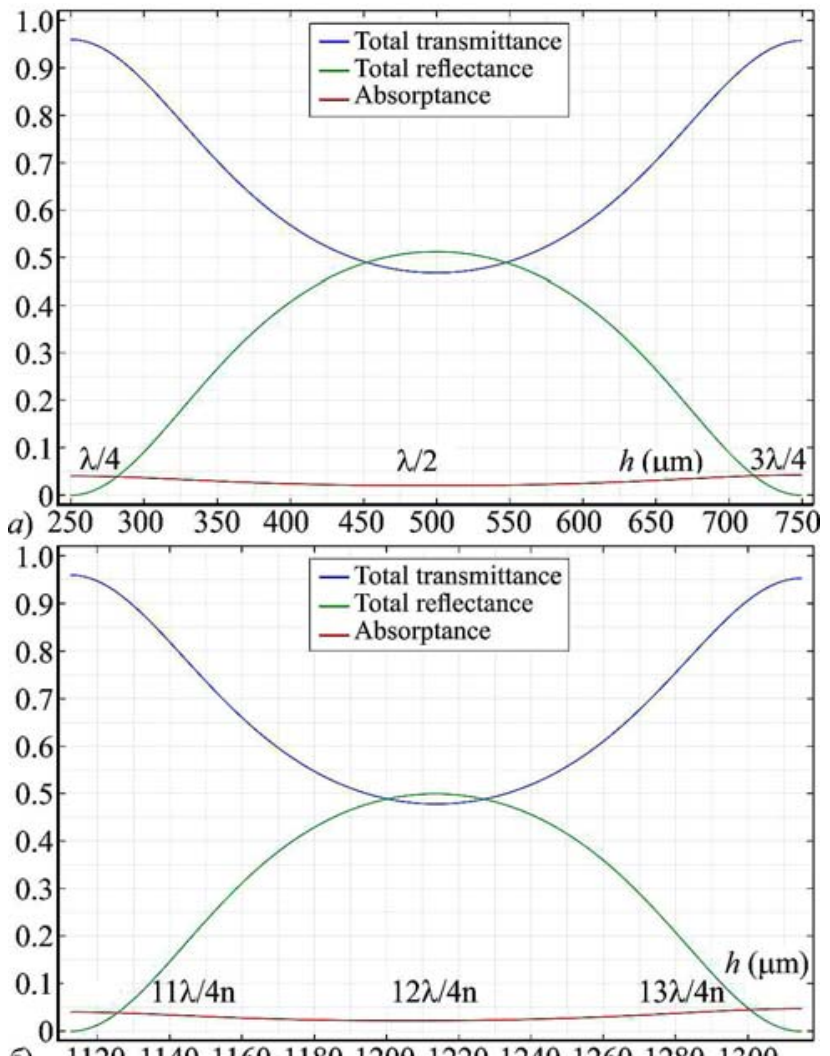

б) 1120114011601180120012201240126012801300

Рис. 7. Обчислені значення пропускання, відбиття та поглинання ТМ поляризованої хвилі залежно від глибини $(a)$ канавок та (b) підкладки
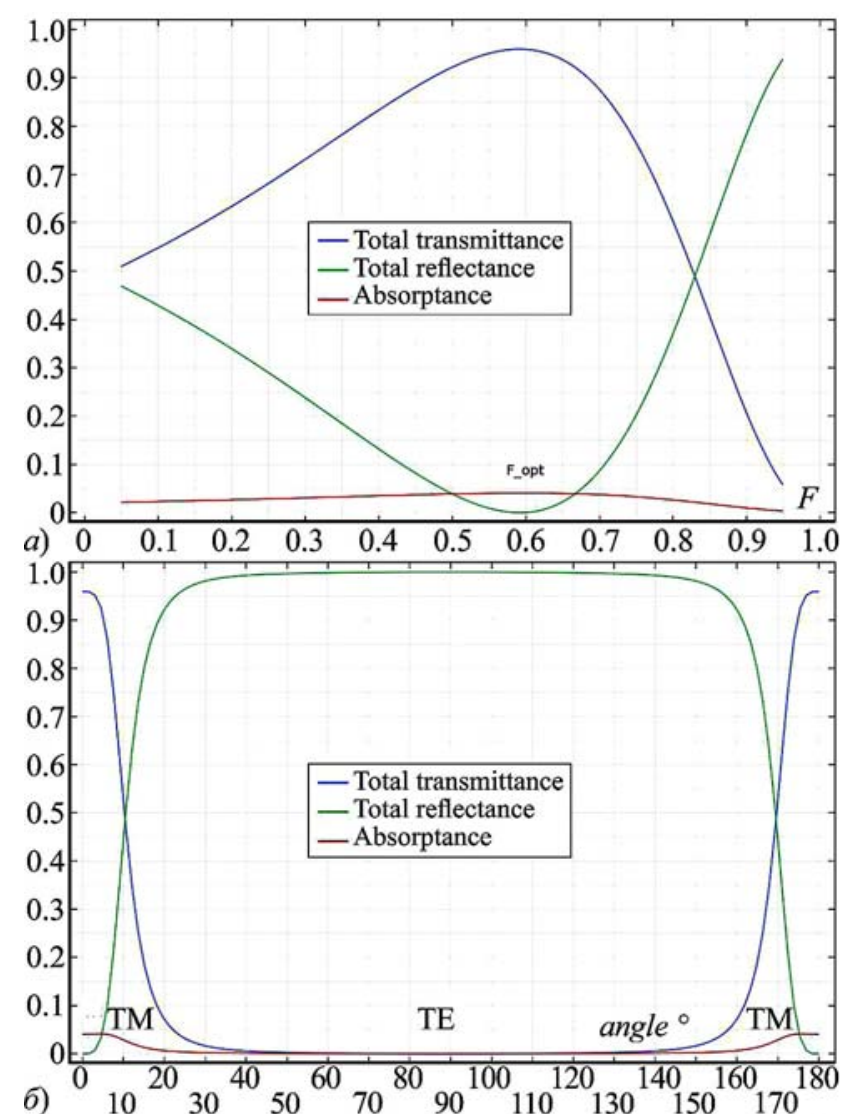

Рис. 8. Обчислені значення пропускання, відбиття та поглинання ТМ хвилі залежно від $(a)$ коефіцієнта заповнення та $(b)$ лінійно поляризованої хвилі залежно від кута падіння (ТМ для $0^{\circ} \rightarrow$ ТЕ для $90^{\circ} \rightarrow \mathrm{TM}$ для $180^{\circ}$ ) 
Як видно з рис. 9, при періоді сітки, що задовольняє умову нульового порядку (1), електромагнітна хвиля, проходячи через поляризатор, не піддається дифракції і коефіцієнт пропускання має відносно стабільні значення. У проміжку періоду сітки між $\lambda_{0} / n_{\text {sub }}$ та $\lambda_{0}$ коефіцієнт пропускання починає стрибкоподібно приймати екстремальні значення. У проміжку від $\lambda_{0}$ до $2 \lambda_{0} \epsilon$ вклад \pm 1 -го порядку дифракції, а в проміжку між $2 \lambda_{0}$ та $3 \lambda_{0}- \pm 2-г о$, і т.д.

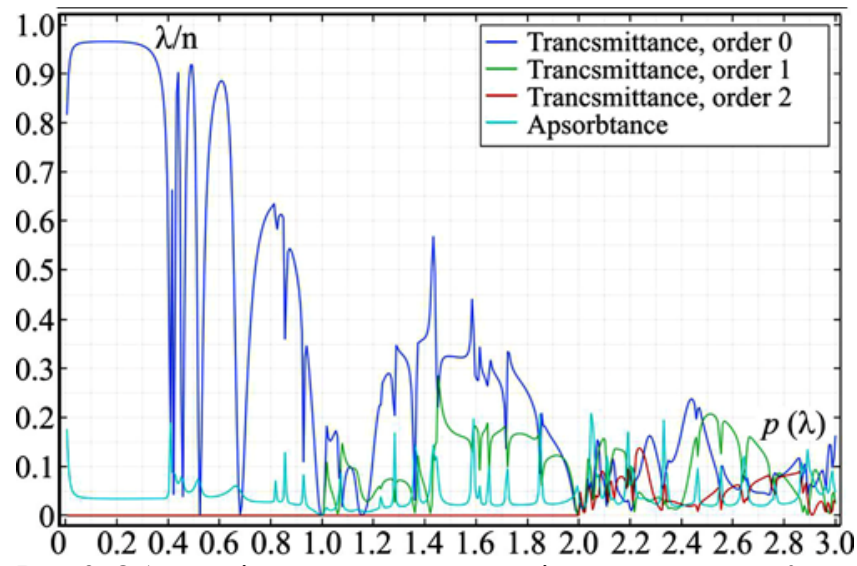

Рис. 9. Обчислені значення поглинання і пропускання для 0-го, \pm 1 -го та \pm 2 -го порядків дифракції ТМ поляризованої хвилі залежно від періоду сітки

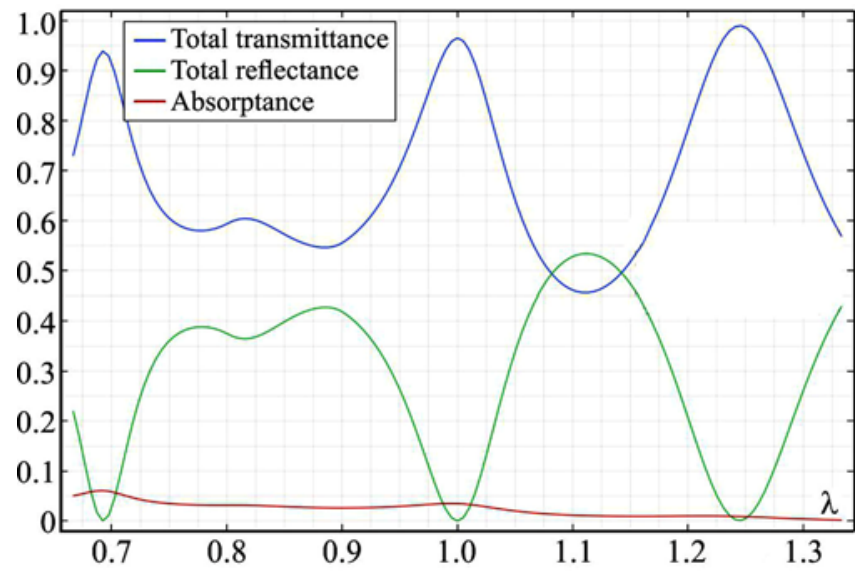

Рис. 10. Обчислені значення пропускання, відбиття та погли-

нання ТМ поляризованої хвилі залежно від довжини хвилі

На рис. 10 зображено зміну характеристик поляризатора при зміні довжини хвилі. Для обчислень використовували значення показників заломлення та коефіцієнтів ослаблення, як функції від довжини хвилі, лінійно інтерпольовані з $[1,38]$ (див. рис. 6). Як видно 3 рис. 10, коефіцієнт пропускання набуває екстремальні значення з нелінійною періодичністю.

Окрім цього, для забезпечення вищих характеристик розробленого поляризатора, нанопористі композити, наповнені іншими кристалічними матеріалами, можуть бути використані як матеріал для підкладки $[5,18,25]$. Використання нанопористих матеріалів демонструє сприятливе застосування як чутливого елемента для оптоелектроніки $[3,4]$.

\section{Висновки}

У роботі подано комбінований числово-аналітичний метод параметричного проєктування підкладкового поляризатора терагерцового електромагнітного випромінювання, побудованого на підставі дротяних сіток. Для цього:
- розглянуто особливості проєктування підкладкового поляризатора терагерцового електромагнітного випромінювання, що будується на підставі дротяних сіток, зокрема здійснено літературний огляд порівняльних характеристик можливих конструкцій поляризаторів різних типів; описано перевагу конструкцій на підставі дротяних сіток; здійснено огляд матеріалів, що використовують для виготовлення відповідних поляризаторів для різної довжини хвилі випромінювання; проаналізовано методи, що використовують для розрахунку характеристик та параметрів поляризаторів на підставі дротяних сіток;

- на підставі цього розроблено комбінований числово-аналітичний метод параметричного проєткування поляризатора терагерцового випромінювання за допомогою аналітичного розрахунку ефективних антивідбивних характеристик конструкції елементарної комірки поляризатора та їх уточнення і розширення за допомогою числового моделювання методом скінченних елементів задачі поширення електромагнітних хвиль у цій конструкції в частотній області зі специфічними граничними умовами, що дає наукову новизну;

- окрім цього, наведено приклад розрахунку параметрів і характеристик підкладкового поляризатора розробленим комбінованим методом для терагерцового випромінювання.

Отримані результати узгоджуються в межах 1 \% похибки 3 передбачуваними теоретичними розрахунками, що свідчить про адекватність та практичну цінність наведеного методу для завдань проєктування терагерцових поляризаторів 3 антивідбивними, високопропускними, низьковтратними та надійними характеристиками.

Окрім цього, завдяки використанню числової скінченно-елементної складової, запропонований метод досить просто розширити шляхом зміни геометрії елементарної комірки для дослідження таких перспективних об'єктів, як багатошарові поляризатори чи поляризатори на підставі складніших мета- чи композиційних матеріалів.

Подяка. Ця робота була виконана за підтримки Мiністерства освіти та науки України в рамках проєкту ДБ/СубТера (номер держрєстрації 0119U100609).

\section{References}

1. Aerosol Refractive Index Archive, Fused Quartz, Refractive index of fused quartz in the far IR range. (2020). Retrieved from: http://eodg.atm.ox.ac.uk/ARIA/data?Minerals/Quartz/(Zhilinskii_et_al._1987)/quartz_Zhilinskii_1987.ri.

2. Ahn, S., et al. (2005). Fabrication of a $50 \mathrm{~nm}$ half-pitch wire grid polarizer using nanoimprint lithography. Nanotechnology, 16(9), 1874-1877. https://doi.org/10.1088/0957-4484/16/9/076

3. Andrushchak, A., et al. (2016). Information technology for most efficient application of bulk and nanocrystalline materials as sensitive elements for optoelectronic devices, TCSET, (pp. 395-398). Lviv. https://doi.org/10.1109/TCSET.2016.7452068

4. Andrushchak, N., et al. (2018). Nanoengineering of anisotropic materials for creating the active optical cells with increased energy efficiency, TCSET, (pp. 484-487). Slavske. https://doi.org/10.1109/TCSET.2018.8336246

5. Andrushchak, N., et al. (2018). Study of second harmonic generation in KDP/Al2O3 crystalline nanocomposite. Acta Phys. Pol. A, 133, 856-859.

6. Andrushchak, N., et al. (2020). Improvement of the Numerical Method for Effective Refractive Index Calculation of Porous Composite Materials Using Microlevel Models, Acta Physica Polonica Series a 133(1), 164-166.

7. Bird, G. R., Parrish, M. (1960). The wire grid as a near-infrared polarizer. J. Opt. Soc. Am. 50, 886-891.

8. Born, M., \& Wolf, E. (2005). Principles of optics: Electromagnetic theory of propagation, interference and diffraction of light, 7-th ed., Cambridge University Press.

9. Brundrett, D. L., et al. (1994). Homogeneous layer models for high-spatial-frequency dielectric surface-relief gratings: conical 
diffraction and antireflection designs, Appl. Opt. 33, 2695-2706. https://doi.org/10.1364/AO.33.002695

10. Chi, N., et al. (2017). High Transmittance Broadband THz Polarizer Using 3D-IC Technologies, 2017 IEEE 67th Electronic Components and Technology Conference (ECTC). Orlando, FL, 1793-1798.

11. Deng, L. Y., et al. (2012). Extremely high extinction ratio terahertz broadband polarizer using bilayer subwavelength metal wire-grid structure, Appl. Phys. Lett. 101, 011101. https://doi.org/10.1063/1.4729826

12. Feng, J., et al. (2011). A Transflective Nano-Wire Grid Polarizer Based Fiber-Optic Sensor. Sensors, 11, 2488-2495. https://doi.org/10.3390/s110302488

13. Ferraro, A., et al. (2016). Flexible terahertz wire grid polarizer with high extinction ratio and low loss. Opt. Lett. 41, 2009-12. https://doi.org/10.1364/OL.41.002009

14. Heavens, O. S. (1965). Optical Properties of Thin Solid Films, 261, Butterworths Scientific Publications, England, 1955. Doover Publications, Inc. https://doi.org/10.1063/1.3059910

15. Hirose, K., et al. (2008). Polarization-transmissive photovoltaic film device consisting of an Si photodiode wire-grid, Journal of Optics A: Pure and Applied Optics, 10(4), 044014. https://doi.org/10.1088/1464-4258/10/4/044014

16. Huang, Z., et al. (2013). Robust Thin-Film Wire-Grid THz Polarizer Fabricated Via a Low-Cost Approach, in IEEE Phot. Tech. Lett., 25(1), 81-84, Jan.1.

17. Jaworski, N., \& Andrushchak, N. (2018). The numerical method for effective refractive index calculatoin of porous composite materials based on microlevel models. Scientific Bulletin of UNFU, 28(6), 140-146. https://doi.org/10.15421/40280628

18. Jaworski, N., et al. (2017). A method of nanoporous anodic aluminum oxide structure modeling based on Bezier curves generation, CADSM. Lviv,

63-66. https://doi.org/10.1109/CADSM.2017.7916085

19. Jaworski, N., et al. (2018). Chislovii metod znakhodzhennia efektivnogo pokaznika zalomlennia poristikh kompozitciinikh materialiv na pidstavi mikrorivnevikh modelei. Scientific Bulletin of UNFU, 28(6), 140-146. https://doi.org/10.15421/40280628

20. Jaworski, N., et al. (2019). Composite Material Microlevel Cellular Model Data Transfer and Verification by FEM Analysis Software Systems, MEMSTECH, (pp. 17-22), Polyana, Ukraine. Retrieved from: https://10.1109/MEMSTECH.2019.8817376

21. Jaworski, N., et al. (2019). Implementation Features of Composite Materials Effective Mechanical Characteristics Finding Method Based on Microlevel Cellular Structural Models, CADSM, (pp. 1-5), Polyana, Ukraine. https://doi.org/10.1109/CADSM.2019.8779273

22. Jin, J. (2014). The Finite Element Method in Electromagnetics, (3rd ed.), John Wiley \& Sons Inc., Hoboken, New Jersey, 876 p.

23. Joannopoulos, J., et al. (2008). Photonic Crystals. Molding the Flow of Light, (1st ed.), Princeton University Press, 305 p.

24. Karman, S. B., et al. (2012). Bio-Inspired Polarized Skylight-Based Navigation Sensors: A Review. Sensors, 12, 14232-14261. https://doi.org/10.3390/s121114232

25. Kulyk, B., et al. (2017). Nonlinear optical response of $\mathrm{KDP} / \mathrm{Al} 2 \mathrm{O} 3$ crystalline nanocomposite, 2017 IEEE 7th International Conference Nanomaterials: Application \& Properties (NAP). Odessa, 03NNSA26-1-03NNSA26-4.

26. Lahtinen, J., \& Hallikainen, M. (1999). Fabrication and characterization of large free-standing polarizer grids for millimeter waves. Int. Jour. of infrared and millimeter waves, 20(1), 3-20. https://doi.org/10.1023/A:1021743415811

27. Liao, Y., et al. (2014). Design of wire-grid polarizer with effective medium theory. Opt Quant Electron 46, 641-647. https://doi.org/10.1007/s11082-013-9768-Z

28. Liu, Y., et al. (2019). High Efficiency Wire Grid Polarizer for Quantum Dot Color Filter LCD. SID Symposium Digest of Technical Papers, 50, 275-278. https://doi.org/10.1002/sdtp.12909
29. Lou, Z., \& Jin, J. (2005). An accurate waveguide port boundary condition for the time-domain finite-element method. In IEEE Transactions on Microwave Theory and Techniques, 53(9), 3014 3023, Sept.

30. Lou, Z., \& Jin, J. (2005). An accurate waveguide port boundary condition for the time-domain finite-element method, 2005 IEEE Antennas and Propagation Society International Symposium, (pp. 117-120). Vol. 1B. Washington, DC https://doi.org/10.1109/APS.2005.1551498

31. Lv, X., et al. (2018). Accurate metrology of freestanding wire polarizer characterization for terahertz sounding. IEEE MTT-S International Wireless Symposium (IWS), 1-3, https://doi.org/10.1109/IEEE-IWS.2018.8400835

32. Meng, F., et al. (2007). The design of the sub-wavelength wiregrid polarizer, 2007 7th IEEE Conference on Nanotechnology (IEEE NANO), 942-946.

33. Microtech instruments inc. (2020). Free Standing Wire Grid Polarizers. Retrieved from: http://www.mtinstruments.com/thzpolarizers/

34. Microtech instruments inc. (2020). THz Polarizers. Retrieved from: http://mtinstruments.com/2017/10/31/thz-polarizers/

35. Moon, S., \& Kim, D. (2006). Fitting-based determination of an effective medium of a metallic periodic structure and application to photonic crystals. J. Opt. Soc. Am. A 23, 199. https://doi.org/10.1364/JOSAA.23.000199

36. Moskalev, V., et al. (1995). Prikladnaia fizicheskaia optika. SPb.: Politekh. [In Russian].

37. Nagibina, I. (1985). Interferentciia i difraktciia sveta, (2nd ed.) Leningrad: Mash. [In Russian].

38. Refractive index database, Optical constants of $\mathrm{Al}$ (Aluminium). (2020). Retrieved from: https://refractiveindex.info/?shelf=main\&book $=$ Al\&page $=$ Hagemann.

39. Ren, L., et al. (2012). Broadband Terahertz Polarizers with Ideal Performance Based on Aligned Carbon Nanotube Stacks. Nano Letters, 12(2), 787-790. https://doi.org/10.1021/nl203783q

40. Shreder, G, \& Traiber, Kh. (2006). Tekhnicheskaia optika. Moscow: Tekhnosfera. [In Russian].

41. Siefke, T., \& Kroker, S. (2018). Polarization Control by Deep Ultra Violet Wire Grid Polarizers. In: Stenzel, O., \& Ohlídal, M. (Eds.). Optical Characterization of Thin Solid Films. Springer Series in Surface Sciences, 64. Springer, Cham. https://doi.org/10.1007/978-3-319-75325-6 13

42. Sun, L., et al. (2010). Double-grating polarizer for terahertz radiation with high extinction ratio, Appl. Opt. 49, 2066-2071. https://doi.org/10.1364/AO.49.002066

43. Takano, K., et al. (2011). Wire-grid polarizer sheet in the terahertz region fabricated by nanoimprint technology. Opt. Lett. 36, 2665 2667. https://doi.org/10.1364/OL.36.002665

44. Trofimov, A. D., et al. (2017). Metal grating terahertz polarizers on substrate, 2017 Progress In Electromagnetics Research Symposium - Spring (PIERS), St. Petersburg, 3223-3225. https://doi.org/10.1109/PIERS.2017.8262311

45. TYDEX. (2020). THz Polarizers. Retrieved from: http://www.tydexoptics.com/products/thz_optics/thz_polarizers1/

46. Xu, L., et al. (2016). Polarization-independent narrow-band optical filters with suspended subwavelength silica grating in the infrared region. Optik 127(2), 955-958. https://doi.org/10.1016/j.ijleo.2015.10.186

47. Xu, M., et al. (2005). Wire-grid diffraction gratings used as polarizing beam splitter for visible light and applied in liquid crystal on silicon, Opt. Ex. 13, 2303-20. https://doi.org/10.1364/OPEX.13.002303

48. Yamada, I., et al. (2009). Terahertz wire-grid polarizers with micrometer-pitch Al gratings. Opt. Lett. 34, 274-276. https://doi.org/10.1364/OL.34.000274

49. Yariv, A., \& Yeh, P. (1983). Optical Waves in Crystals. NY: John Wiley \& Sons.

50. Zhe, H. (2015). Design and Fabrication of Terahertz Thin Film Polarizer, PhD thesis, City University of Hong Kong. 


\section{COMBINED NUMERICAL-ANALYTICAL METHOD OF TERAHERTZ SUBSTRATE-BASED WIRE GRID POLARIZER PARAMETRIC DESIGN}

The features of the terahertz substrate-based wire grid polarizer designing are considered in the work. For this purpose, a literature review of different type polarizer constructions comparative characteristics was presented and the advantage of wire grid constructions was described. An overview of the materials used for the manufacture of suitable polarizers for different radiation wavelengths is given. Based on this, a combined numerical-analytical method of terahertz polarizer parametric design was presented in the paper. The method consists of effective anti-reflective characteristics analytical calculation of the polarizer unit cell structure and their further refinement and expansion by numerical finite element simulation of the electromagnetic wave propagation problem within this structure in the frequency domain with specific boundary conditions. This brings the scientific novelty. The anti-reflective characteristics calculations are based on the analytical effective medium theory which enables designing polarizer as a thin dielectric film with minimum reflectance. The finite element model considers a polarizer unit cell as a waveguide with specific periodic and port conditions. The combination of both approaches brings the possibility to design a polarizer grid and substrate sizes which provide minimum reflectance. An example of terahertz substrate-based polarizer parameters and characteristics calculation by the developed combined method was given. The obtained results are consistent within $1 \%$ error with the assumed theoretical calculations that were obtained by other scientific group. This indicates the adequacy and practical value of the proposed method for the design of polarizers with anti-reflective, high-transmittance, low-loss and robust characteristics. In addition, by using a numerical finite element component, the proposed method is quite simple to extend by changing the geometry of the unit cell to study such promising objects as multilayer polarizers or polarizers based on more complex meta- or composite materials.

Keywords: finite element method; unit cell; waveguide; antireflection film; transmittance. 